\title{
Participation of Plasma Membrane H+-ATPase in Seed Germination
}

\author{
Obroucheva $\mathrm{NV}^{*}$ \\ Russian Academy of science, Russia
}

Submission: March 10, 2017; Published: May 03, 2017

*Corresponding author: Obroucheva Natalie, Institute of plant physiology of Russian Academy of science; Botanicheskaya str.35, Moscow 127276, Russia; Tel: +7 (499) 6785330: Fax:+7 (499) 6785420; Email: n.obroucheva@mail.ru; obroucheva@ippras.ru

Abstract

The review considers the possibility of PM H+-ATPase contribution to the initiation of cell elongation in embryo cells of germinating seeds. The enzyme activated prior to growth initiation is responsible for $\mathrm{H}+$-ion transport out of cytoplasm and cell wall acidification resulting in its loosening and extensibility.

Keywords: Seed germination; Cell elongation; PM-H+-ATPase activation; Cell wall acidification.

\section{Introduction}

Seed germination represents a rapid transformation of quiescent seed to growing seedlings occurring under favorable conditions of water supply, temperature and aeration. It starts by elongation of embryo cells and manifests itself in a root tip protrusion through the seed coat, so-called radicle emergence. The initiation of germination is mainly determined by elongation of embryo cells, whereas cell proliferation starts either synchronously or later. The advantage of cell elongation is a rapid increase in cell length (twenty fold or even more) while cell division results only in twofold increase during one cycle in almost the same time interval [1]. Such rapid germination provides the availability of soil water and successful germination. Rapid cell elongation also occurs in growing plant organs, for example, hypocotyl and epicotyls extending stem apex to light or in coleoptile pushing upward the first leaf in cereals.

The mechanism of their cell transition to elongation is known as an "acid-induced" growth [2]. It comprises acid-induced loosening of cell wall polymers and its higher extensibility that permits cell to increase the volume or length under the pressure of entering water, being a prerequisite for growth beginning. Such acidification of cell walls occurs due to operation of plasma membrane $\mathrm{H}+$-ATPase (PM H+-ATPase), a transmembrane enzyme, well-known by its energetic functioning, which is accompanied by the transport of protons from cytoplasm to cell walls [3]. The aim of this review is to show that the initiation of cell elongation in germinating seeds is due to activation of plasma membrane H+-ATPase. The data were partly published in [4].

\section{Demonstration of acid-induced seed germination}

Three different types of seeds were investigated, namely broad beans Vicia faba minor, horse chestnut Aesculus hippocastanum and wheat Triticum durum. They germinated at optimum temperature in wet filter paper moistened either with water or with $1 \mathrm{mM}$ phosphate-citrate buffer, $\mathrm{pH} 3.9$ (Figure 1). The data confirmed that an acid-induced mechanisms stimulates the beginning of seed germination. Then this possibility was tested in experiments with embryos excised from cotyledons or endosperm of imbibing in water seeds. The capacity to acidify the ambient solution was measured. The embryos were incubated in $1 \mathrm{mM} \mathrm{KCl}$ solution of $\mathrm{pH} 6.2$ for measuring the $\mathrm{pH}$ shift (Figure 2). The data show acidification of ambient solution by protons extruded by embryos. In all three types of seeds, the acidification started at water contents preceding the initiation of cell elongation. Therefore, the embryo cell wall acidification underlies the commencement of seed germination. 


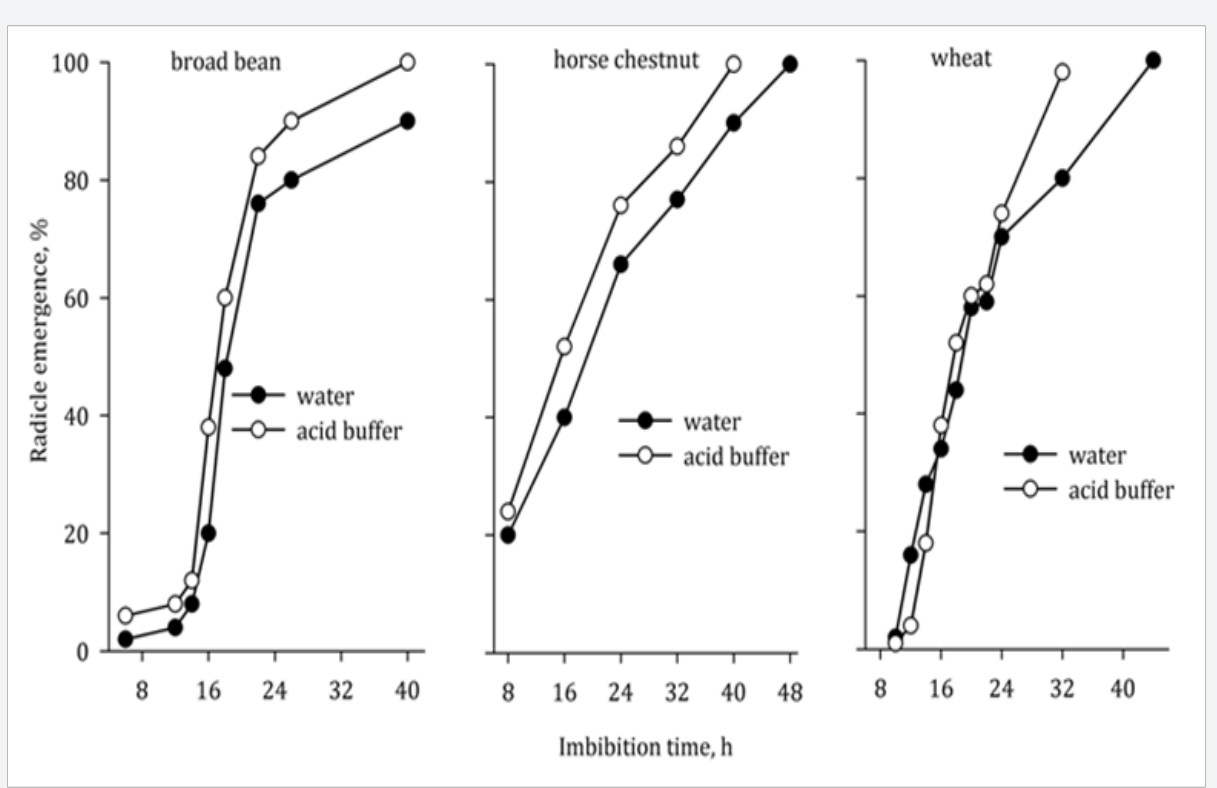

Figure 1: Seed germination in acid buffer.

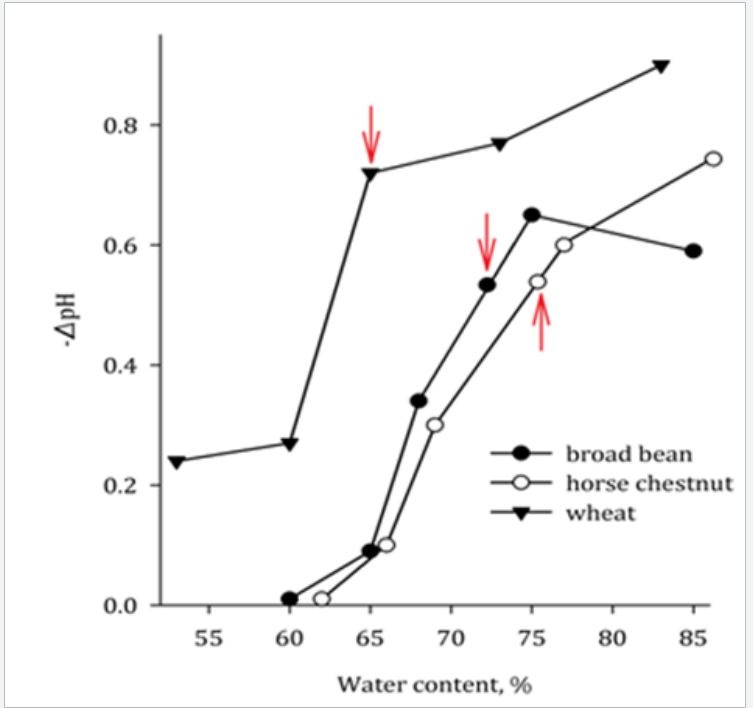

Figure 2: Acidification of ambient solution by seed embryos. Arrows indicate growth initiation.

\section{Participation of PM H+-ATPase in acid-induced seed germination}

For identification of PM H+-ATPase activity, the test with fusicoccin is usually applied. The excised embryos of broad beans, horse chestnut and wheat were incubated in $5 \cdot 10-5 \mathrm{M}$ fusicoccin that resulted in acidification increase by factor 1.5 . Therefore, cell wall acidification prior to growth initiation is due to the activation of $\mathrm{H}+$-ATPase localized in plasma membranes of embryo cells. Side by side with the evaluation of acidifying capacity of PM H+-ATPase in embryos of germinating seeds, we observed there an elevation of typical PM H+-ATPase activity measured as accumulation of phosphate ions after ATP hydrolysis [5]. Figure 3 shows an activation of ATP hydrolysis at growth initiation in the embryos of imbibing horse chestnut seeds and its further increase in 1.5-2.0cm-long embryos growing by cell elongation. The same regularity was observed in imbibing, germinating and growing embryos of broad beans. The rise of hydrolytic activity of PM H+-ATPase in germinating embryos was inhibited by $5 \bullet 10-3 \mathrm{M}$ orthovanadate, a structural analogue of phosphate ion. Thus, the testing of embryos with fusicoccin and orthovanadate is a good evidence for PM H+ATPase to operate as a germination-regulating protein. 


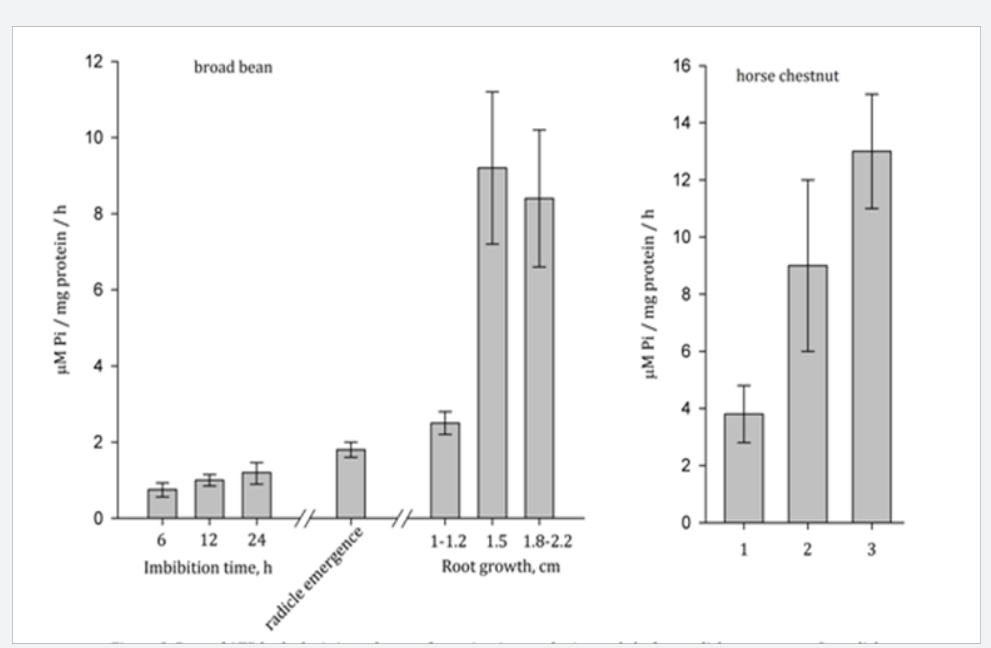

Figure 3: Rate of ATP hydrolysis in embryos of germinating seeds. 1-seeds before radicle emergence, 2- radicle emergence, 3- growth after radicle emergence.

\section{Activation of PM H+-ATPase}

From the aforesaid it follows that PM H+-ATPase activity is very low in embryos of seeds before germination, rises during seed imbibition, is high at growth initiation and maintains at this level during growth. Such activation was not suppressed by $10 \mu \mathrm{M}$ cycloheximide, an inhibitor of protein synthesis, and by $5 \mu \mathrm{M} \alpha$-amanitin, an inhibitor of new mRNA transcription. These experiments indicated that the enzyme molecules are not synthesized in the course of imbibition neither on preformed nor on newly formed mRNA molecules. The presence of this enzyme was shown in the embryos of dry maize seeds [6]. They exert a weak activity after 5h-long imbibition, not accompanied by protein synthesis [7]. The presence of PM H+-ATPase in microsomal fractions of seed embryos was confirmed also immunochemically with specific antibodies (Agrisera, Sweden) (Figure 4).Therefore, seed embryo preparation for germination includes an activation of preexisted enzyme molecules, i.e. their transition from autoinhibited state to an active state.

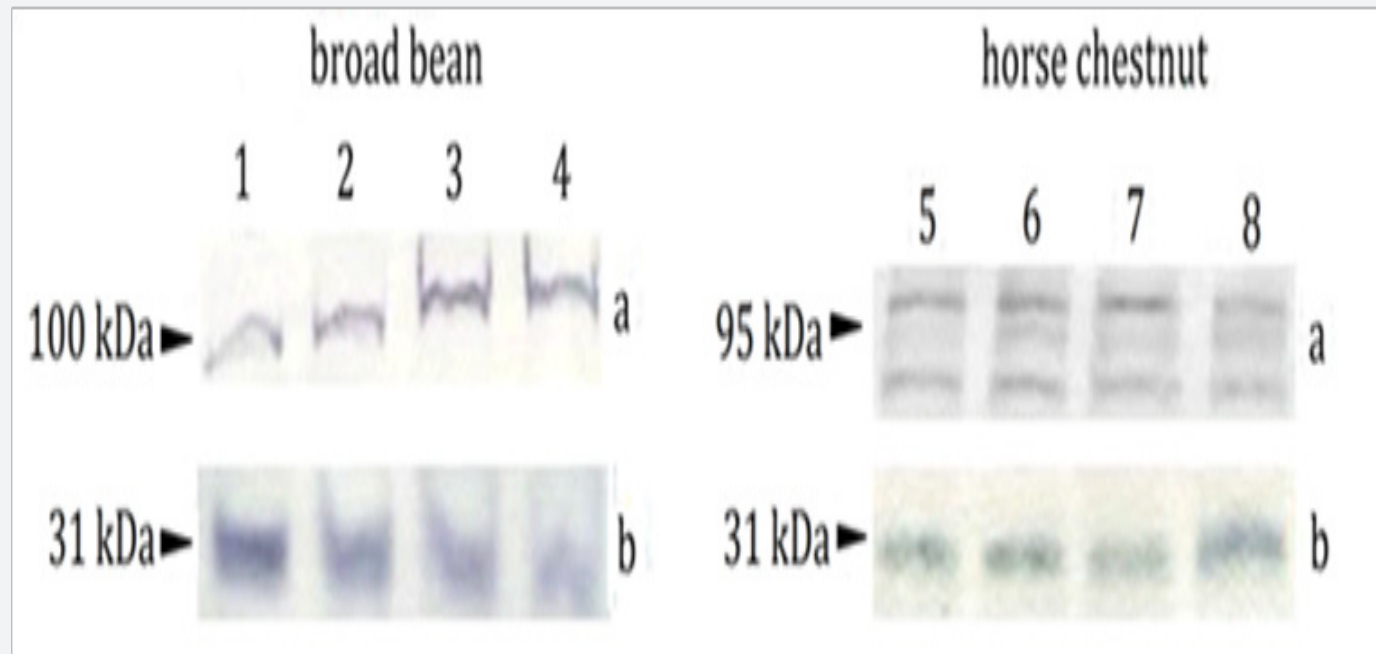

Figure 4: Immuno chemical identification of PM H+- ATPase(a) and 14-3-3 proteins (b) in embryos of germinating seeds. 1-imbibition, water content(wc) $40 \%$; 2-imbibition, wc 60\%; 3-radicle emergence, wc 72-73\% , 4-growth; 5- wc 62\%; 6-imbibition, wc 64-66\%; 7- radicle emergence, wc 73-74\%; 8-growth.

According to the wide-spread point of view, the autoinhibited form of PM ATPase molecule can be activated by the phosphorylation of penultimate Thr-947in C-regulatory cytoplasmic domain that results in displacement of this domain and the binding of 14-3-3 protein. Such binding of regulatory 14-
3-3 protein is stabilized by fusicoccin [8]. It is not the intent of this review to go into the history of this notion. It is important to add that phosphorylation at site Thr-881 also enhances the enzyme activity, whereas two other sites (Ser-899 and Ser-931) decrease it [9]. Recently, the displacement of cytoplasmic $\mathrm{N}$ 
domain was also shown to be coupled to the modifications in $\mathrm{C}$ terminal by modulating the accessibility of protein kinases to Thr-947 [10]. Great attention is now paid to the action of lipids on PM H+-ATPase activity [11]. Specific activation of PM $\mathrm{H}+$-ATPase by lysophospholipids in Arabidopsis was shown to depend on glycerol backbone and length of acyl chain [12].

The mechanism of PM H+-ATPase activation in germinating seeds still remains unclear. The seed embryos contain enzyme protein side by side with 14-3-3 proteins (Figure 4) during the activation, growth initiation and later on during cell elongation in growing organs. The activation is promoted by fusicoccin. These findings indicate that activation in seeds is regulated conceptually identical to other plants. However, it is tempting to suppose that in seeds endogenous fusicoccin provides the success of germination as fusicoccin-like ligands were found in the embryos of germinating broad bean and horse chestnut seeds [13].

\section{Conclusion}

With three different types of seeds, it was demonstrated that PM H+-ATPase plays an important role in seed germination due to its activated capacity to supply cell walls with $\mathrm{H}+$-ions necessary for cell elongation commencement in embryos.

\section{Acknowledgement}

The author is grateful to PhD Lityagina S. and Sinkevich I. for cooperation and assistance.

\section{References}

1. Obroucheva N (1999) Seed germination: a guide to the early stages. Backhuys Publishers, Leiden, the Netherland, p.158.

2. Hager A (2003) Role of plasma membrane H+-ATPase in auxin-induced elongation growth: historical and new aspects. J Plant Res 116(6): 483505 .
3. Buch-Pedersen MJ, Pedersen BP, Veierskov B, Nissen P, Palmgren MG (2009) Protons and how they are transported by proton pumps. Eur J Physiol 457(3): 573-579.

4. Obroucheva NV, Sinkevich IA, Lityagina SV, Novikova GV (2013) Activation of "acid" growth in germinating horse chestnut seeds. Russ. J. Plant Physiol 106(3): 41-46.

5. Janicka-Russak M, Kabala K, Wdowikowska A, Klobus G (2012) Response of plasma membrane $\mathrm{H}+$-ATPase to low temperature in cucumber roots. J Plant Res 125(2): 291-300.

6. Sanchez-Nieto S, de Gomez-Puyou MT, Rodrigez-Sotres R, Garballo A, Gavilanes-Ruiz M (1998) Comparison of plasma membrane H+-ATPase actvity in vesicles obtained from dry and hydrated maize embryos. Biochim. Biophys. Acta 1414(1-2): 175-187.

7. Sanchez-Nieto S, Enriquez-Arredondo C, Guzman-Chavez F, HernandezMunoz R, Ramirez J, et al. (2011) Kinetics of the H+-ATPase from dry and 5-hours-imbibed maize embryos in its native, solubilized and reconstituted forms. Mol Plant 4(3): 505-515.

8. Camoni L, Visconti S, Aducci P (2013) The phytotoxin fusicoccin a selective stabilizer of 14-3-3 interactions? Int. Union Biochem Mol Biol 65(6): 513-517.

9. Haruta M, Gray W M, Sussmann MR (2015) Regulation of plasma membrane proton pump ( $\mathrm{H}^{+}$-ATPase $)$by phosphorylation. Curr Opinion Plant Biol 28: 68-75.

10. Ekberg K, Palmgren MG, Veierskov B, Buch-Pedersen MJ (2010) A novel mechanism of P-type ATPase autoinhibition involving both termini of the protein. J Biol Chem 285(10): 7344-7350.

11. Morales-Cedillo F, Gonzalez-Solis A, Gutierrez-Angus L, Cano-Ramirez DL, Gavilanes-Ruiz M (2015) Plant lipid environment and membrane enzymes: the case of the plasma membrane $\mathrm{H}^{+}$-ATPase. Plant Cell Rep 34: 617-629.

12. Wielandt AG, Pedersen JT, Falhof J, Kemmer GC, Lund A, et al. (2015) Specific activation of the plant P-type plasma membrane $\mathrm{H}^{+}$-ATPase by lysophospholipids depends on the autoinhibitory $\mathrm{N}$ - and C-terminal domains. J Biol Chem. 290(26): 16281-16291.

13. Antipova OV, Bartova LM, Kalashnikova TS, Obroucheva NV, Voblikova VD, et al. (2003) Fusicoccin induced cell elongation and endogenous fusicoccin-like ligands in germinating seeds. Plant Physiol Biochem 41: 157-164.

\section{Your next submission with Juniper Publishers will reach you the below assets}

- Quality Editorial service

- Swift Peer Review

- Reprints availability

- E-prints Service

- Manuscript Podcast for convenient understanding

- Global attainment for your research

- Manuscript accessibility in different formats

( Pdf, E-pub, Full Text, Audio)

- Unceasing customer service

Track the below URL for one-step submission

https://juniperpublishers.com/online-submission.php 